\title{
The Art Hero Made International—Benjamin West Constructs Wolfe's Death on the Plains of Abraham
}

\author{
Lloyd James Bennett \\ Thompson Rivers University, Kamloops, Canada
}

\begin{abstract}
Globalization is a topic much discussed today with the explosion of cell phones and instant messaging. This exchange of information causes the art historian to ponder the speed with which ideas spread in past centuries. The eighteenth was a century of colonial expansion made possible through the ships that sailed the great oceans. Sea travel between Europe and North America drastically increased the spread of populations and their ideas between the old and new world. A good way to trace the exchange of ideas in picture painting in the eighteenth century would be to follow an artist like Benjamin West from his Quaker background in Pennsylvania to the center of the neoclassical style in Rome and a prolific career in London at the Royal Academy. West's travels and career offer an example of how an American pursued the artistic style of contemporary Rome to make images of North American history from a base in England. It was globalization eighteenth-century-style made possible by an ambitious artist connecting across the sea-lanes of international travel.
\end{abstract}

Keywords: painting, history, globalization, neoclassicism, eighteenth century, West, Wolfe

Wolfe must not die like a common soldier under a bush.... To move the mind there should be a spectacle presented to raise \& warm the mind \& all shd be proportional to the highest idea conceived of the Hero.... A mere matter of fact will never produce the effect. ${ }^{1}$

\section{Introduction}

The 18th century was a period of extensive trade and immigration between Europe and North America made possible by sea travel. This contact not only influenced the amount of trade goods between the old and new worlds but it facilitated the exchange of cultural ideas. The last half of the century saw the emergent of the neoclassical style in art and architecture, having its origins in Rome, expanded to other European countries and North America. The style was in part a reaction to the frivolous rococo, which, when associated with the French court, put art on a hedonist track that lacked the morality that the neoclassicists in Rome wished to see in art. Benjamin West, growing up in Quaker Pennsylvania, readily adopted this art style that had at its center morality and the idea of self-sacrifice. Using West's biography by John Galt, the author will examine the youth and travels of the painter to Rome for confirmation of the neoclassical style brought to fruition in London at the Royal Academy. It will be in his history paintings of North America that West

\footnotetext{
Lloyd James Bennett, Ph. D., associate professor, Department of Visual and Performing Arts, Thompson Rivers University. ${ }^{1}$ University of Toronto, Thomas Fisher Rare Book Library, Walker Papers, Box 24, Walker to Borden, 15 April 1918. The painting was acquired for the Canadian War Memorials Fund as a gift to Canada from the Duke of Westminster.
} 
would spread his view of the sacrificing hero with his revolutionary painting "The Death of Wolfe" of 1770.

There is seeded in the biographic material of American expatriate painter Benjamin West a natural pride in those things North American, which the artist would bring to the forefront of history painting at the Royal Academy, London in the mid-eighteenth century. The story of the artist first seeing the "Apollo Belvedere" (Roman marble copy of a Greek original, late fourth century B.C.) with Cardinal Albani in Rome has been repeated several times: "When the keeper threw open the doors, the Artist felt himself surprised with a sudden recollection altogether from the gratification which he had expected. 'My God, how like a young Mohawk warrior!’” (Galt, 1816, pp. 105-106; Staley, 1989, p. 16; Flexner, 1967, p. 21). West’s reference point for nobility in stature of the antique god was Pennsylvania and when he blurted out his first impression he was recounting his home state and had to explain to the assembled Italians that he was not comparing the statue to a "savage" but to the nobility of the North American native. It might be a trivial misunderstanding but it marks a literal account where an artist referenced a non-European type as a model for great art. West would take the lead in bringing histories like "The Death of Wolfe" (1770) to the noble tradition of history painting.

\section{John Galt’s Biography}

John Galt published his biography of Benjamin West in two volumes (1816 \& 1820) and claimed that the artist had read and approved the manuscript ${ }^{2}$ (Galt, 1816, p. 13). Galt's account focused on the early years of the artist life where we read that Benjamin West was born at Springfield, Chester County, Pennsylvania in 1738 of Quaker parents. The boy showed an interest in the study of nature and learned from the local "Indians" who taught him how to make paint:

In the course of the summer a party of Indians came to pay their annual visit to Springfield, and being amused with the sketches of birds and flowers which Benjamin sowed them, they taught him to prepare the red and yellow colours with which they painted their ornaments.... The Indians also taught him to be an expert archer.... practice at shooting birds for their plumage would look well in a picture. (Galt, 1816, p. 18)

Soon friends of the West family began noticing the young artist's work and encouraged him with gifts of paints and engravings for study. When the schoolmaster observed West's absenteeism, his mother became appeased "in her anger" with the sight of her son's artwork (Galt, 1816, p. 23).

Upon moving to Philadelphia, West encountered a series of influential men who would help shape the artist's career. The first of these appeared to be the artist William Williams who introduced West to books on painting by Charles Alphonse du Fresnoy and Jonathan Richardson ${ }^{3}$ (Galt, 1816, p. 28). Galt tells us that these books would have been "conversational” points for the young artist to advance his ideas on painting. The gunsmith William Henry read to West the account of the Death of Socrates, from an English translation of Plutarch $^{4}$ (Helmbold, 1939, p. 369), that would have further advanced this inculcation to noble history. West

\footnotetext{
${ }^{2}$ West scholar Annette Wickham goes as far as to suggest it had been "ghost written" by Galt for the artist. See Royal Academy of Arts, RA Collections, "Benjamin West PRA History Painter to the King” (accessed October 3, 2012).

${ }^{3}$ Benjamin West American painter at the english court, These books were du Fresnoy's De arte graphica, in the translation of 1695 by John Dryden... and probably Richardson's Accounts of Sins of the Saints, Bas-Reliefs, Drawings and Pictures in Italy of 1722.

${ }^{4}$ The passage reads, "Do you mix a cup of poison? Did you not present this to Socrates also? And cheerfully and calmly, without trembling or changing either colour or posture, he drained it with great cheerfulness; and as he died the living esteemed him happy, believing that 'not even in Hades would he be without same god-given portion'”.
} 
would make a painting of the subject of Greek tragedy (c. 1756) which set him on a path as a history painter of the noblest subjects attracting “much attention” (Galt, 1816, p. 37; Staley, 1989, p. 14).

The picture indicated that West was already learned in the classical composition of European art. Socrates is placed off centre in the design balanced by an armored soldier who remains transfixed by what he is witnessing. A man wearing a toga who has just handed the cup of hemlock to Socrates marks the central axis of the room. Above, large round arches frame the figure groups on either side as they respond to the scene over a stone floor marked with perspective lines. The picture has much of the absorption of secondary figures of Leonardo da Vinci's work and has the stage-like feel of Nicholas Poussin's painting from the seventeenth century; West could have seen the styles of these artists through book engravings ${ }^{5}$. Indeed, the eighteenth century had sufficient trade and immigration to make the dissemination of books and images readily available to North America viewers who might ponder the Mediterranean hero Socrates as he comes sacrificing in his antique toga.

Galt's narrative continues with an account of Reverend William Smith, the Provost of the College of Philadelphia, who admires the "Socrates" and gives West "a sketch on the taste and character of the spirit of antiquity” (Galt, 1816, p. 38; Staley, 1989, p. 14). The biographer’s words are close to Joshua Reynolds, the first president of the London Royal Academy and future friend of West, in that they sing the praises of antique art. Reynolds wrote in his third discourse that "we must have recourse to the ancients as instructors" (Reynolds, 1891, p. 92), which Galt appears to be recording from the lips of West himself who recalls an appropriate story with Reverend Smith to carry the message. Indeed the biography remains an account the artist wished to give in terms of childhood anecdotes and promotion of artistic talent. In this the artistic genius, that Reynolds so admired in antique artist Phidias, runs from Galt’s pen with unabashed celebration. Consider these lines after the sermon by John Williamson:

At the conclusion of this address, the women rose and kissed the young Artist, and the men, one by one, laid their hands on his head and prayed that the Lord might verify in his life the value of the gift which had induced them, in despite of their religious tenets, to allow him to cultivate the faculties of his genius.... That he was authorized by his friends and his religion, to cultivate the art by which he attained such distinctions, not for his own sake, but as an instrument chosen by Providence to disseminate the arts of peace in the world. (Galt, 1816, pp. 56-57)

The fact that West could recount such a moment to his biographer suggests that he proceeded in his career with a consciousness of a divine gift for art from his youth or that he embellished the story with hindsight towards a philosophy that paralleled his co-founding of the London academy with the intent to shape the world (Rather, 2004, pp. 324-345) ${ }^{6}$. "He had global ambition”7 was the way West commentator Loyd Grossman put it—he was to take on big things that would translate across a great ocean.

\section{Italian Experience}

The literature and engravings that came into West's view in America set an appetite for great stories where

\footnotetext{
${ }^{5}$ The source for West painting “The Death of Socrates” comes from an engraving in Charles Rollins' Ancient History (1730-1738).

${ }^{6}$ Rather makes the point that while there were earlier biographies on West these focused on his British interests because the artist was seeking to "to facilitate his identification as head of the English school of painting" and become the president of the Royal Academy.

7 Royal Academy of Arts, RA Collections, “Benjamin West PRA History Painter to the King” (accessed Oct. 3, 2012).
} 
heroes sacrificed for truth and the common good. This philosophy had had taken root in the second half of the eighteenth century in Rome and became known as neoclassical revival. West anxious to move his painting along in this direction of principled art had to travel to Italy to complete his self-taught education. After a brief attempt at portrait painting in New York, the aspiring artist landed in Leghorn on 16 June 1760 (Galt, 1816, pp. 81-84; Staley, 1989, p. 16). Galt tells us that it was not long before West was in Rome, "the shrine of antiquity” (Galt, 1816, p. 97). Here West made the rounds of Roman monuments such as the previously mentioned Apollo and a statue "ascribed to Phidias, on the Monte Cavallo" (Galt, 1816, p. 107). The North American connection was brought home again in the pages that follow in Galt's memoir where human connectedness was attempted:

Of all the monuments of ancient art in Rome, the Obelisk brought from Egypt, in the reign of Augustus, interested his curiosity the most. The hieroglyphics appeared to resemble so exactly the figures in Wampum belts of the Indians that it occurred to him, if even the mysteries of Egypt were to be interpreted, it might be by the aborigines of America. (Galt, 1816, p. 132)

While these antique monuments were picked out for praise, West concluded that Rome had fallen to “disease” and that "the moral energy [of the city] was subsiding” (Galt, 1816, p. 146).

In this position of the neoclassical attitude West would have been adopting the approach of artists like Gavin Hamilton and Rachael Mengs ${ }^{8}$, who were based in Rome to revive the earlier classical style to invigorate art to return to its position of influence and morality. This would be the lesson of the eternal city for the American artist West as he made his way North.

\section{London Career}

After a brief tour of French collections that West condemned for “corrupt taste” (Galt, 1816, p. 155), the artist arrived in England in August 1763 with lodgings at Covent Garden. Throughout his travels West had used introductory letters and the assistance of men of influence to move his career along and this proved most fortuitous in London. In Venice the artist had met Richard Dalton, who was the librarian to King George III, and from this contact West was able to secure his first commission from the King ${ }^{9}$ (Staley, 1989, p. 17; Weintraub \& Ploog, 1987, pp. 33, 49). Royal patronage would mark West’s career in England as he would paint several pictures for George III and be appointed “Historical Painter to the King” (Staley, 1989, p. 16).

The English were far behind the French who had mastered the use of art to promote the reign of the monarch. The French Academy was founded in the 17th century with the primary purpose of promoting family rule of Louis XIII and his successor Louis XIV with history painting. King George III saw in West a man with the abilities to produce British history in the Grand Manner of European painting. The road to West's acceptance as a history painter was once again lined with supporters who were anxious to help the expatriate American. Galt tells that Lord Rockingham had offered the artist $£ 700$ a year "to paint historical subjects for his mansion in Yorkshire” (Galt, 1816, p. 9). One of West’s most influential supporters the Archbishop of York took a lead in suggesting historical titles to the artist such as the Tacitus story of Agrippina returning the ashes of Germanicus.

\footnotetext{
${ }^{8}$ Galt writes that West met Mengs at Cardinal Albani's villa and suggested the artist should visit "Florence, Bologna, Parma, Venice”, see p. 122.

9 The painting was "Cymon and Iphigenia" and was painted in Rome in 1763. A sepia drawing of the subject signed by West in 1788 exists in a private collection.
} 
Not to be left out of suggestions for history painting, the King suggested West paint the departure of Regulus from Rome. However, the painting to bring the most attention to the history painter West was a contemporary scene from the colonies, "The Death of Wolfe", painted in 1770, caused a sensation before and after its exhibition at Pall Mall.

By all accounts "The Death of Wolfe” brought international attention to the artist from Pennsylvania. During the eighteenth century Britain was the chief exporter of engravings and West's picture, engraved by William Woolett, became an enormous world success bringing in $£ 15,000$. The interest in the picture in London came from the recognition that the "British global empire was being created" and that the people back home had a "mania for news" about this expansion ${ }^{10}$ (Grossman, 2012).

This interest in overseas expansion can be seen in the 1768 publication of the Scenographia Americana produced by a group of London publishers of a series of 28 scenes of North America. All of the images were drawn by British officers such as Capt. Hervey Smyth, Wolfe's Aid de Camp, and show the British fleet in picturesque settings such Louisbourg and Quebec City. The engravings showed not only the might of the British forces but also what the places looked like "during the Seven Years War" (Crowley, 2006; British Officers, 1768). The conclusion to this journey with the troops would be West's painting of the death of the British commander that awaited the visitor to the 1771 exhibition of the Royal Academy exhibition.

There were some who criticized the artist for creating an ennobled scene for the death of the young commander. West had also included portraits of officers around Wolfe, but none of these would have been present at the place where the commander died. When questioned on these points of accuracy West alluded to the necessity to elevate the death of a hero:

It must exhibit the event in a way to excite awe \& veneration \& that which may be required to give superior interest to the representation must be introduced, all that can show the importance of the Hero. Wolfe must not die like a common soldier under a [b]ush.... To move the mind there should be a spectacle presented to raise \& warm the mind \& all shd. be proportional to the highest idea conceived of the Hero.... A mere matter of fact will never produce the effect. ${ }^{11}$

In this West was following the classical model of idealizing the hero as he saw in "The Apollo Belvedere" and works by Phidias. Now "The hero of Quebec” would forever die a noble death sacrificing for the British Empire. In the pyramidal composition and stage-like setting the painter had in fact capture the gravitas of a European history painting in all manners save for one. The players on the stage above the St. Lawrence River were not in antique clothing - a point that would bring the artist much controversy and attention.

According to Galt, the King heard of the painting of Wolfe in progress and despaired that the figures would not follow the formula for history painting by having the figures in togas.

The King mentioned that he heard much of the picture, but he was informed that the dignity of the subject had been impaired by the latter circumstance observing that it was very ridiculous to exhibit heroes in coats, breeches, and cock'd hats. (Galt, 1816, p. 47)

Royal Academy president Joshua Reynolds was called in for an opinion and the artist proceeded to make his case for contemporary clothing:

\footnotetext{
${ }^{10}$ Royal Academy of Arts, RA Collections, "Benjamin West PRA History Painter to the King”.

11 Walker Papers, Box 24, Walker to Borden, April 15, 1918.
} 
I began by remarking that the event intended to be commemorated took place on the $13^{\text {th }}$ of September, 1758 , in a region of the world unknown to the Greeks and Romans, and at a period of time when no such nations, not heroes in their costumes, any longer existed. The subject I have to represent is the conquest of a great province of America by the British troops. It is a topic that history will proudly record, and the same truth that guides the pen of the historian should govern the pencil of the artist. (Galt, 1816, p. 48)

Reynolds was convinced by the argument and proclaimed that "this picture will not only become one of the most popular, but occasion a revolution in the art” (Galt, 1816, p. 49). With this support from the president of the Royal Academy, West had changed history painting to include contemporary military uniforms while bringing in North America into the genre of history painting.

Uniforms aside, the picture was pure in its classical ideals of showing Wolfe and his attendants in a pyramidal construction below the Union Jack. There were some such as actor David Garrick who thought the attitude all wrong and, with the assistance of visitors to the Pall Mall, produced what he thought a real "rapture felt by the dying general when he heard the cry 'They run, they run'” (Whitley, 1928, p. 282). Perhaps Garrick was reaching for a theatrical moment not considered by the artist who has Wolfe adopt the look of a "pieta" as suggested by art historians, who thought the death a religious one that promoted the general to the pantheon of the gods, at least the English gods (Shama, 1990, pp. 14-56; Vaughan, 1978, p. 59).

Indeed the death scene is a fiction, Wolfe died off of the battlefield in his tent, constructed to elicit sympathy for the young commander whose position is supported by those friends and officers who witness his death, all absorbed in the sacrifice like a religious scene. The central group is framed by the knelling Mohawk who ponders the death of the commander and a hatless, red-coated grenadier who wrings his hands in anticipation of death. These repoussoirs represent old and new world interests - the Georgian military in a distant land and the local native musing over imperial adventure. The native figure was criticized for accuracy of costume (no moccasins) and accuracy of being at this battle (McNairn, 1997, p. 137). It was, however, part of the artist's mission to depict North America and its inhabitants in this new approach to history painting in contemporary clothing as a spiritual sacrifice. The link between the spiritual and the empire would not have been wasted on those who saw the British expansion around the world as a moral imperative from the Quakers of New England to the settlers in colonial Canada who flew the flag of the mother country.

\section{Colonial Trade}

It would be the globalization of the eighteenth century that saw expatriate artist Benjamin West from Pennsylvania carries with him his Quaker beliefs back to the country of his parent's origin to make a history painting on North American conquest. The middle decades of the eighteenth century were focused on exchange with the colonies that included as one historian put it: "nails, axes, firearms, buckets, coaches, clocks, saddles, handkerchiefs, buttons, cordage and a thousand other things" (Davis, 1969, p. 106). This growth reached its peak during the Seven Years War (ended with Treaty of Paris 1763) where overseas garrisons required goods that set trade routes from Britain. New World contact opened the door for not only exchange of goods but also decimated the philosophies and art styles contained in books that expanded European traditions.

This interest in a contemporary hero found its greatest effect not in private collections, but in the reproduction market pioneered by William Hogarth who reproduced his paintings in print form for the mass market. This greatly extended the field of influence an old master or contemporary artist might assume with is art. 
As for the reputation of Benjamin West, it continued to grow based upon the popularity of his picture of Wolfe reaching mass appeal with William Woollett's engravings. In fact the two had become so financially linked that when Woolett died, a public committee formed in 1781 raised funds for a memorial to be placed in Westminster Abbey. West, then president of the Royal Academy, attempted to get an inscription commenting on "The Death of Wolfe” included in the plaque but was overturned by the committee (McNairn, 1997, p. 151).

After his achievement in England, West turned to his supporters once again to promote his artistic success. His mentor Reverend Smith had been to London and would on returning to Pennsylvania promote the American as a great success overseas. This shift to discuss West as an American artist was, as Susan Rather writes, an attempt to earn "a prominent place in American art history as a mentor" (Rather, 2004, p. 341) by supporting his biographer Galt to play up the formative years of the artist's life. If Reynolds could not be dislodged from the title of father of British painting, West could rightfully claim that title for himself in his native country made all the more possible by the flow of information between nations that had been established in the eighteenth century.

\section{Conclusions}

It is an interesting note that when Wolfe's body arrive at Spithead, 17 November 1759, the sculptor Joseph Wilton was dispatched by the Duke of Richmond to record the face of the deceased. In his book Behold the Hero (1997), Alan McNairn described Wilton's marble bust of the commander as a "Roman general, with some concession to contemporary fashion and symbolism such as the gorget, wolf-head epaulettes (a visual pun), and the lion of England in relief on the antique breastplate” (McNairn, 1997, p. 62).

The sculpture was acquired by the National Gallery of Canada in 1975 and is exhibited beside West's original painting "The Death of Wolfe”, part of Lord Beaverbrook's War Memorials Collection from the First World War. Wilton's bust makes the final allusion to the art hero made international as belonging to the legends of antiquity that West sought to promote in his painting without the Roman dress.

\section{References}

British Officers. (1768). Scenographia Americana: Or, a collection of views in North America and the West Indies. London: John Bowles, Robert Sayer, Thomas Jefferys, Henry Parker.

Crowley, J. E. (2006). Scenographia Americana (1768): A transnational landscape for early America. Common-Place, 6(2). Retrieved from http: //www.common-place.org

Davis, R. (1969). English foreign trade, 1700-1774. In W. E. Minchinton (Ed.), The growth of english overseas trade in the seventeenth and eighteenth centuries (p. 106). London: Methuen.

Flexner, J. T. (1967). America's old masters. New York: Dover.

Galt, J. (1960). The life of Benjamin West 1816-1820. Gainesville: Scholars Facsimiles and Reprints.

McNairn, A. (1997). Behold the hero: General Wolfe \& the arts in the eighteenth century. Liverpool: Liverpool University press. Plutarch (1939). Moralia (Vol. VI). (W. C. Helmbold, Trans.). London: William Heinemann.

Rather, S. (2004). John Galt, and the biography of 1816. The Art Bulletin, 86(2), 324-345.

Reynolds, J. (1891). Sir Joshua Reynolds discourses. Chicago: A. C. Mc Clurg and Co..

Shama, S. (1990). The many deaths of general Wolfe. Granta, 32, 14-56.

Staley, A. (1989). Benjamin West: American painter at the english court. Baltimore: The Baltimore Museum of Art.

Vaughan, W. (1978). Romantic art. New York and Toronto: Oxford University Press.

Weintraub, S., \& Ploog, R. (1987). Benjamin West drawings from the historical society of Pennsylvania. University Park, Pennsylvania: Museum of Art.

Whitley, W. T. (1928). Artists and their friends in England 1700-1799 (Vol. I). London and Boston: The Medici Society. 